\title{
The Leech airway: precursor to the modern supraglottic airway
}

\author{
Emma C. Avery, MSc®
}

Received: 30 November 2017/Accepted: 30 November 2017/Published online: 20 December 2017

(C) Canadian Anesthesiologists' Society 2017

The Leech airway or "Pharyngeal Bulb Gasway", was patented $^{\text {A }}$ in 1937 by Dr. Beverley C. Leech (1898-1960). Born in Brandon, Manitoba, Dr. Leech served in World War I as a Lieutenant in the Canadian Infantry. He obtained his medical degree from McGill University in $1925^{1}$ and later became the director of anesthesia at the Regina General Hospital. He is currently recognized as one of the pioneers of Canadian anesthesia.

The main driving force for inventing what came to be called the Leech airway was the increasing popularity of cyclopropane-based anesthesia, which required a semiclosed system for administration due to its volatility and relative expense. ${ }^{2}$ Leech's objective was to design a onesize-fits-all device that could create a tight seal within the airway without the need for intubation (which was a relatively tedious and time-consuming procedure compared with today's intubations). ${ }^{\mathrm{B}}$ To achieve this goal, Leech created pharyngeal wax casts from cadavers to assess the general size and shape of the human adult pharynx and determine its "average size". ${ }^{1}$ The Leech airway was used in patients undergoing ear, nose, head and neck, and ophthalmic procedures. ${ }^{2}$ It was especially noted for its superiority over other means of administering nitrous oxide during minor dental procedures and tooth extractions. ${ }^{3}$

The Leech airway is often regarded as the inspiration for, and precursor to, the original Laryngeal Mask Airway $\left(\mathrm{LMA}^{\mathrm{TM}}\right.$; Teleflex Inc.), which was developed during the early 1980s by the British anesthesiologist Archie Brain,

\section{E. C. Avery, MSc ( $\square)$}

Faculty of Medicine, St. Boniface Hospital, University of Manitoba, CR3008-369 Tache Avenue, Winnipeg, MB R2H

2A6, Canada

e-mail: averye@myumanitoba.ca

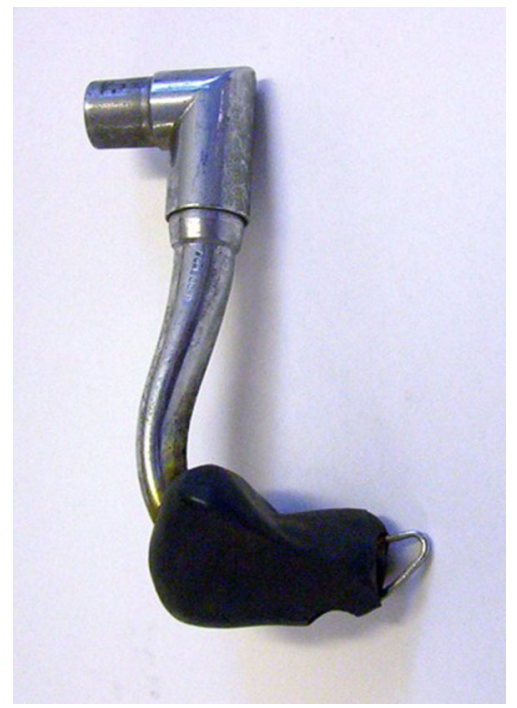

Figure Photograph of the Leech airway (from the archives of the Canadian Anesthesiologists' Society)

who cited Leech's airway in his own patent application. ${ }^{\mathrm{C}}$ The main difference between the two devices is that the

\footnotetext{
${ }^{A}$ Leech $B C$. Pharyngeal bulb gasway. Patent for the Leech airway filed on December $30^{\text {th }}, 1936$. Patent was granted on November $16^{\text {th }}$, 1937 (US patent number 2099127 A). Available from URL: https:// www.google.com/patents/US2099127 (accessed December 2017).

B Maltby JR. Leech pharyngeal bulb gasway. The History of Anaesthesia Society Proceedings. Proceedings of the Summer Scientific Meeting - $25^{\text {th }}$ and $26^{\text {th }}$ June 2010 - volume 42: 95-101. Available from URL: http://www.histansoc.org.uk/uploads/9/5/5/2/ 9552670/9865-1.pdf (accessed December 2017).

C Brain AI. Artificial airway device. Patent for supraglottic airway device filed on December $16^{\text {th }}$, 1981. Patent was granted on December $14^{\text {th }}$, 1982 (US patent number 4509514 A). Available from URL: https://www.google.com/patents/US4509514 (accessed December 2017).
} 
Leech airway was positioned higher in the pharynx than the LMA. The Leech airway was widely used well into the late 1950s, after which its use declined. The primary reason for its waning use was the introduction of suxamethonium. In a letter $^{\mathrm{D}}$ written by Leech in 1957 , he said "I rarely use it myself anymore, since rapid acting relaxants have made intubation so simple". 4

Conflicts of interest None declared.

Editorial responsibility This submission was handled by Dr. Hilary P. Grocott, Editor-in-Chief, Canadian Journal of Anesthesia.

\section{References}

1. Griffith HR. Obituary Beverley Charles Leech. Can Anaesth Soc J 1960; 7: 351-2.

2. Leech $B C$. The pharyngeal bulb gasway: a new aid in cyclopropane anesthesia. Anesth Analg 1937; 16: 22-5.

3. Sherwin $L W$. The pharyngeal gasway; its use in exodontia. Dent Items Interest 1947; 69: 342-4.

4. Haridas RP. The Leech airway or pharyngeal bulb gasway. Anaesth Intensive Care 2011; 39(Suppl 1): 5-10.

D Leech BC. Letter to Dr. Intress 13 March 1957. Wood Library Museum of Anesthesiology, Park Ridge, Illinois. 